\title{
IL-21R signaling is critical for induction of spontaneous experimental autoimmune encephalomyelitis
}

\author{
Youjin Lee, ${ }^{1}$ Meike Mitsdoerffer, ${ }^{2}$ Sheng Xiao, ${ }^{1}$ Guangxiang Gu, ${ }^{1}$ Raymond A. Sobel, ${ }^{3}$ and Vijay K. Kuchroo ${ }^{1}$ \\ 'Evergrande Center for Immunologic Diseases, Brigham and Women's Hospital, Harvard Medical School, Boston, Massachusetts, USA. ${ }^{2}$ Klinikum Rechts der Isar, Department of Neurology, \\ Technical University Munich, Munich, Germany, and Munich Cluster for Systems Neurology (SyNergy), Munich, Germany. ${ }^{3}$ Palo Alto Veteran's Administration Health Care System \\ and Department of Pathology, Stanford University School of Medicine, Stanford, California, USA.
}

\begin{abstract}
IL-17-producing CD4 ${ }^{+}$T cells (Th17 cells) have well-described pathogenic roles in tissue inflammation and autoimmune diseases, such as experimental autoimmune encephalomyelitis (EAE); however, the involvement of IL-21 in these processes has remained controversial. While IL-21 is an essential autocrine amplification factor for differentiation of Th17 cells, the loss of IL-21 or IL-21 receptor (IL-21R) does not protect mice from actively induced EAE. Here, we utilized a transgenic EAE mouse model, in which $\mathrm{T}$ and $\mathrm{B}$ cells overexpress receptors for myelin oligodendrocyte glycoprotein (MOC) (referred to as $2 \mathrm{D} 2 \mathrm{xTH}$ mice), and demonstrated that IL-21 is critical for the development of a variant form of spontaneous EAE in these animals. I/21r deletion in 2D2xTH mice reduced the incidence and severity of spontaneous EAE, which was associated with a defect in Th17 cell generation. Moreover, IL-21R deficiency limited IL-23R expression on Th17 cells and inhibited expression of key molecules involved in the generation of pathogenic Th17 cells. Conversely, loss of IL-23R in 2D2xTH mice resulted in complete resistance to the development of spontaneous EAE. Our data identify a previously unappreciated role for IL-21 in EAE and reveal that IL-21-mediated signaling supports generation and stabilization of pathogenic Th17 cells and development of spontaneous autoimmunity.
\end{abstract}

\section{Introduction}

Multiple sclerosis (MS) is an inflammatory demyelinating disease of the central nervous system (CNS) that is thought to be driven by pathogenic $\mathrm{CD}^{+}$Th cells $(1,2)$. Experimental autoimmune encephalomyelitis (EAE) is an animal model that recapitulates many of the clinical and pathological features of MS $(3,4)$. Multiple different models of EAE have been developed in different animal species; most of them depend on immunization of susceptible animals with a myelin antigen in $\operatorname{CFA}(3,5,6)$. More recently, TcR transgenic mice have been generated for myelin basic protein (MBP) and proteolipid protein (PLP) on PL/J and SJL backgrounds, respectively; these TcR transgenic mice develop spontaneous paralytic disease without any need for immunization, with inflammatory lesions that are uniformly distributed throughout the optic nerves, brain, and spinal cords $(7,8)$. We also generated myelin oligodendrocyte glycoprotein-specific (MOG-specific) TcR transgenic mice (2D2) on a C57BL/6 background; very few, if any, of these mice develop spontaneous EAE, but approximately $50 \%$ of these MOG-TcR transgenic mice develop spontaneous optic neuritis (9). When 2D2 TcR transgenic mice are crossed onto MOG-specific B cell receptor "knockin" mice (named TH), approximately $60 \%$ of these mice develop spontaneous disease by 6 weeks of age (10). The inflammatory lesion distribution in these 2D2xTH mice with spontaneous disease is generally restricted to the optic nerve

Authorship note: Youjin Lee and Meike Mitsdoerffer contributed equally to this work. Conflict of interest: The authors have declared that no conflict of interest exists. Submitted: June 4, 2015; Accepted: August 17, 2015.

Reference information: / Clin Invest. 2015;125(11):4011-4020. doi:10.1172/JCI75933. and spinal cord while sparing the brain; hence, the disease is to some extent similar to a subtype of MS called neuromyelitis optica (NMO) or Devic's disease (10). Thus, in the 2D2xTH mice, collaboration between MOG-specific T and B cells results in a spontaneous disease that shares some features with NMO $(10,11)$. The cytokines and effector molecules that result in the development of this spontaneous disease in 2D2xTH mice have not been elucidated. This is particularly important, since most of the cellular and cytokine requirements for EAE have been elucidated from the mice that were actively immunized with myelin antigens in CFA.

Initially, Th1 cells were thought to be critical for the induction of EAE, as IFN- $\gamma$-secreting cells are present in CNS lesions (12). However, the observation that both Ifng $\mathrm{KO}$ and Ifngr $\mathrm{KO}$ mice develop EAE raised the possibility of involvement of a Th subset other than Th1 cells in the induction of EAE (13-15). With the identification of IL-23 as a critical cytokine responsible for the development of EAE, a new subset of Th cells was discovered; these are called Th17 cells and are present at sites of autoimmune tissue inflammation (16). This new subset was found to be functionally distinct from Th1 or Th2 cells, required a master transcription factor orphan nuclear receptor (ROR $\gamma \mathrm{t}$ ), and produced IL-17A, IL-17F, IL-21, IL-22, and GM-CSF $(17,18)$. The development of active EAE is inhibited in mice that lack IL-17, IL-17R, and GM-CSF, thus illustrating the role of the Th17-associated cytokines as a critical factor in the development of encephalitogenic T cells (19-21).

The differentiation of naive $\mathrm{CD} 4^{+} \mathrm{T}$ cells into Th17 cells takes place in 3 distinct but overlapping steps: induction, amplification, and stabilization, where TGF- $\beta 1$ plus IL- 6 (or TGF- $\beta 1$ plus IL-21) induces, IL-21 amplifies, and IL-23 stabilizes the phenotype of 

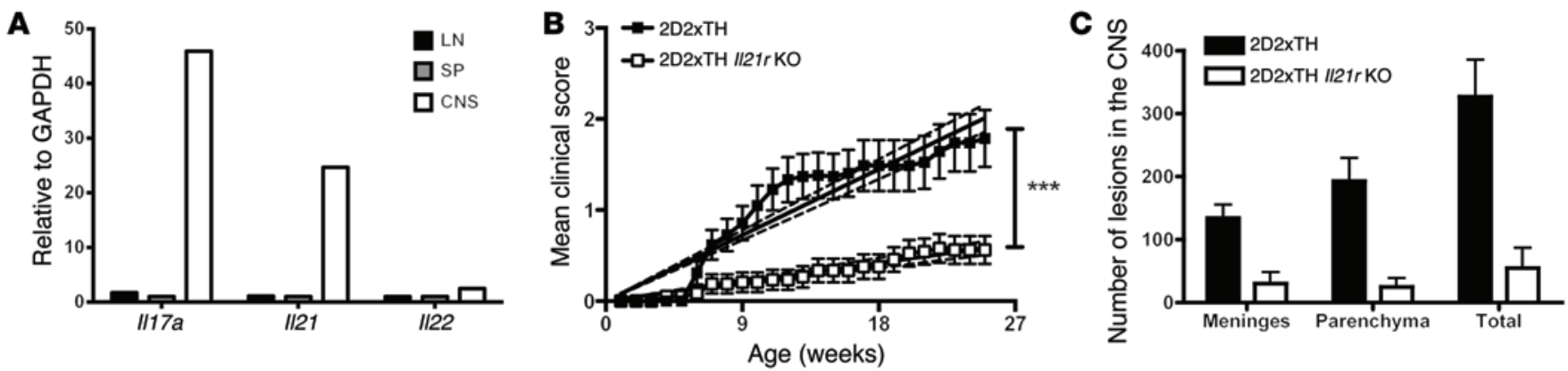

D
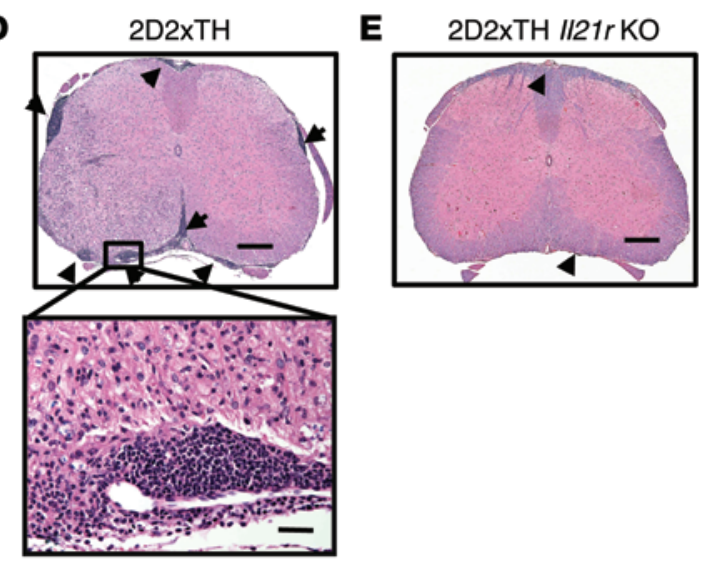

H

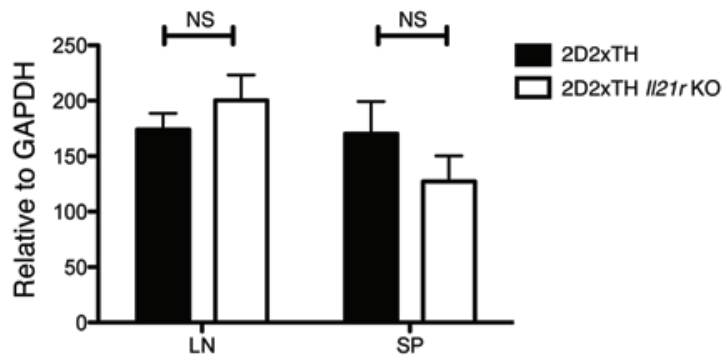

J $2 \mathrm{D} 2 \times \mathrm{TH}$
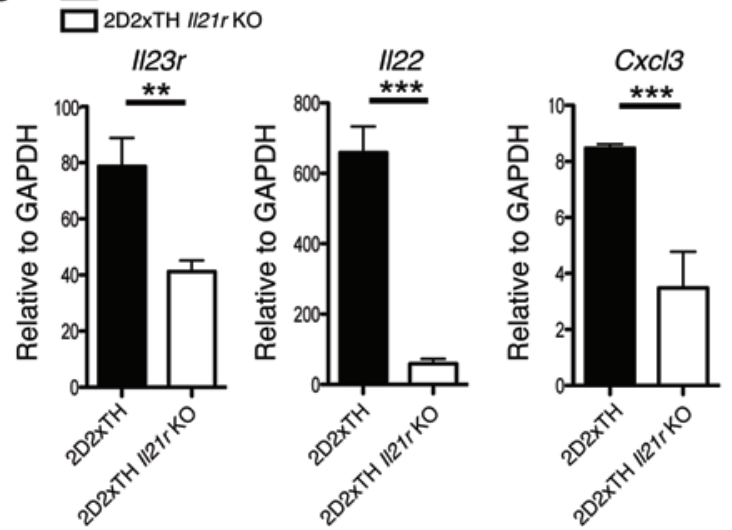

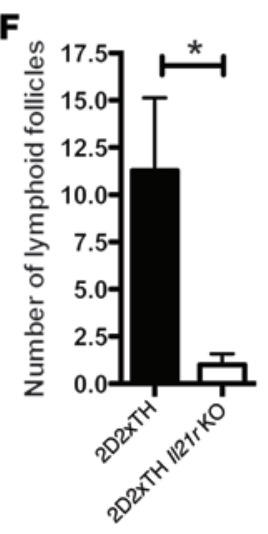

G<smiles>C[13CH2]O</smiles>

2D2xTH
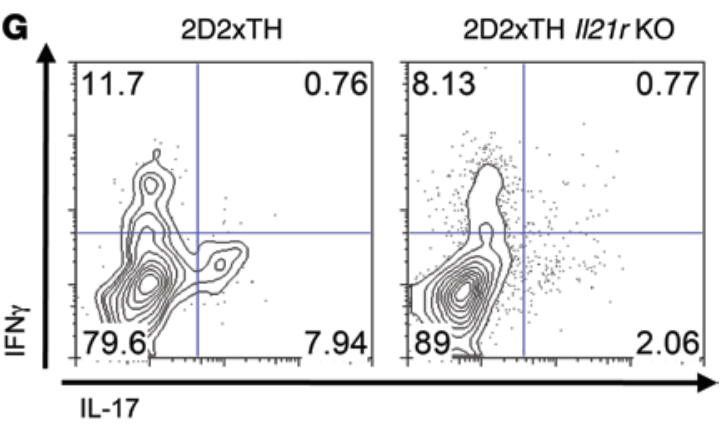
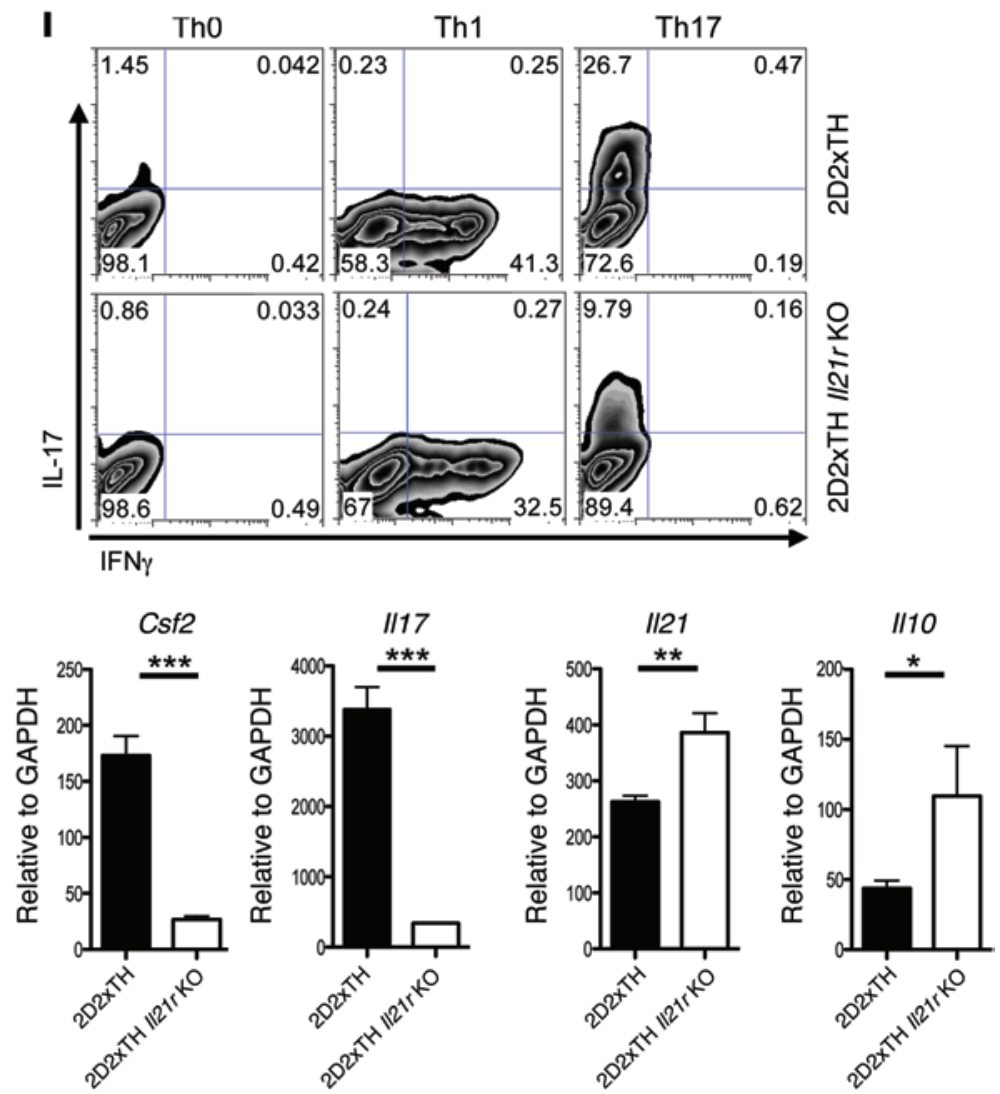
Figure 1. 2D2xTH II21r KO mice have decreased incidence of spontaneous EAE. (A) Quantitative RT-PCR from 2D2 T cells sorted from the CNS, LNs, and SP of 2D2xTH mice that developed EAE. (B) Incidence of EAE from 2D2xTH $(n=63)$ and $2 \mathrm{D} 2 \times \mathrm{TH} / 121 r \mathrm{KO}(n=43)$ mice. Statistical analysis by linear regression curve was graphed with the $95 \%$ confidence band of the regression line. (C) Quantification of the CNS lesions. (D and E) Paraffin sections of the spinal cord from indicated mice at the peak of disease stained with luxol fast blue and H\&E. Meningeal and parenchymal inflammatory infiltrates and meningeal lymphoid follicles are shown (arrows). Inset in $\mathbf{D}$ is shown at $\times 10$ magnification in lower panel. Scale bars: $200 \mu \mathrm{m}$ (D, upper panel; E); $20 \mu \mathrm{m}$ (D, lower panel). (F) Quantification of meningeal lymphoid aggregates in the CNS from $2 \mathrm{D} 2 \times \mathrm{TH}$ $(n=7)$ and 2D2xTH I/21r KO $(n=5)$ mice that developed EAE. (G) Intracellular cytokine staining of IFN- $\gamma$ and IL-17 from 2D2 T cells in the CNS from indicated mice that developed EAE. (H) Quantitative RT-PCR of 2D2 $T$ cells isolated from the LNs and SP from indicated mice that developed EAE $(n=3)$. (I) Intracellular cytokine staining of IFN- $\gamma$ and IL-17 from naive $\mathrm{CD}^{+}{ }^{+} \mathrm{T}$ cells from $2 \mathrm{D} 2 \times \mathrm{TH}$ and $2 \mathrm{D} 2 \times \mathrm{TH} / 121 \mathrm{r} \mathrm{KO}$ mice differentiated for 4 days in vitro with no cytokines (Th0), IL-12 (Th1), and TCF- $\beta 3 /$ IL-6 (Th17). (J) Quantitative RT-PCR from 2D2 T cells that were differentiated with TGF- $\beta 3 /$ IL- 6 (Th17) for 4 days in vitro. Statistics were determined by 2 -tailed Student's $t$ test. ${ }^{*} P<0.05$; ${ }^{* *} P<0.01 ;{ }^{*} P<0.001$. Data shown are representative of $\mathbf{3}(\mathbf{A}-\mathbf{H})$ or 4 ( $\mathbf{I}$ and $\mathbf{J})$ total experiments. Data represent mean \pm SEM for figures $\mathbf{A}-\mathbf{C}, \mathbf{F}, \mathbf{H}$, and $\mathbf{K}$. A represents pooled samples from $n=3$ mice for each experiment.

developing Th17 cells (22-25). Loss of TGF- $\beta$, IL-6, or IL-23 cytokines or their receptors inhibits the development of EAE in mice actively immunized with a myelin antigen $(16,26,27)$. However, the role of the amplification factor, IL-21, has been controversial in EAE. Initially, IL-21 and IL-21 receptor (IL-21R) were thought to be critical in the induction of EAE (28), but subsequent experiments showed that the loss of either IL-21 or IL-21R did not protect mice from developing $\operatorname{EAE}(29,30)$. In sharp contrast, multiple studies have shown that IL-21 plays a critical role in the pathogenesis of another spontaneous autoimmune disease, type 1 diabetes (T1D), in nonobese diabetic (NOD) mice (31). This raises the question of whether the requirement of IL-21 in actively induced EAE is obscured due to the massive activation of the innate immune system provoked by the active immunization with the adjuvant CFA and, as a consequence, may override the need for IL-21 to amplify development of pathogenic effector $\mathrm{CD}^{+}{ }^{+} \mathrm{T}$ cells. Furthermore, autoreactive B cells play a critical role in the development of spontaneous T1D in NOD mice, and the requirement of IL-21 observed in the T1D model may be due to the critical role of IL-21/IL-21R on $B$ cell function, which in turn has an effect on the development of spontaneous T1D. Since 2D2xTH mice develop spontaneous EAE and $\mathrm{B}$ cells play a critical role in the onset, our model provides us with an ideal system to test the role of IL-21 and other Th17-associated cytokines in the development of spontaneous disease that is not dependent on active immunization involving CFA.

Here, we report that $2 \mathrm{D} 2 \mathrm{xTH}$ mice at the peak of disease have CNS-infiltrating $\mathrm{CD}^{+} \mathrm{T}$ cells that produce large amounts of Th17 cytokines, including IL-17, IL-21, and IL-22. Activated B cells produce IL-23 in this model system, which may be responsible for stabilizing Th17 cells. To elucidate the mechanism of Th17 pathogenicity in this model, we crossed 2D2xTH mice to IL-21R- and IL-23R-deficient mice. Our study reveals that, contrary to what occurs in actively induced EAE models, IL-21 plays a critical role in the development of spontaneous EAE in 2D2xTH mice. In addition, IL-23R deficiency provides complete protection from disease. Furthermore, we identify molecular mechanisms by which IL-21 regulates the development of this spontaneous disease model, which may represent a useful therapeutic target for MS and NMO.

\section{Results}

2D2xTH Il21r KO mice have decreased incidence of spontaneous EAE. We had previously reported the generation of a new mouse model (2D2xTH) where the cooperation of both $\mathrm{T}$ and $\mathrm{B}$ cells that are specific for the myelin antigen MOG results in the development of spontaneous and highly progressive EAE (10). Our differential microarray analysis of $\mathrm{T}$ cells from the CNS of the mice with spontaneous EAE from 2D2 versus 2D2xTH mice revealed that Th17associated genes are overexpressed in the 2D2xTH mice (data not shown). To confirm our microarray data, we isolated cells from the CNS, lymph nodes (LNs), and spleen (SP) of 2D2xTH mice at the peak of clinical EAE, sorted for $\mathrm{CD}^{+} \mathrm{T}$ cells, and performed quantitative reverse-transcriptase PCR (RT-PCR) on Th17-associated cytokines. Our data revealed that mRNA expression of $I l 17 a$, Il21, and Il22 was increased in the CNS of the sick 2D2xTH mice compared with the peripheral immune compartment (SP and LNs) (Figure 1A), suggesting that Th17-associated cytokines are in fact expressed at high levels in the CNS of mice that develop spontaneous EAE. Since the role of IL-21 has been controversial in the induced EAE disease models, we specifically examined the role of IL-21 in this spontaneous NMO-like disease model, where MOGspecific $\mathrm{T}$ and $\mathrm{B}$ cells collaborate to induce disease.

To address the role of IL-21, we generated 2D2xTH Il21r KO mice and monitored the mice for the development of spontaneous paralysis. In contrast to reported studies with active EAE induction, mice that lacked IL-21R had decreased incidence and severity of disease compared with the 2D2xTH control group (Figure 1B and Table 1). Histopathological analysis of the CNS revealed that 2D2xTH Il21r KO mice had a decreased number of lesions in both the meninges and parenchyma of the spinal cord compared with 2D2xTH mice (Figure 1C), thus supporting our clinical disease incidence data. We have previously reported that the $\mathrm{T}$ and $\mathrm{B}$ cells in the CNS lesions in 2D2xTH mice accumulated in the subarachnoid spaces of the spinal cord in aggregates and formed ectopic lymphoid follicle-like structures with a reticulin lining (10). In the absence of IL-21R, the number of lymphoid follicle-like structures in the CNS was also significantly reduced (Figure 1, D-F). This was especially surprising, as previous studies $(29,30)$ reported that IL-21 was dispensable for the development of EAE. Our data reveal an important role not only for Th17 cells, but also for IL-21 in the development of spontaneous NMO-like disease when the mice express both TcR and BcR specific for the same myelin antigen, MOG. Interestingly, in other animal models of spontaneous autoimmune diseases, such as T1D, the requirement of IL-21/IL-21R signaling has been shown to be essential (31-33). This is further supported by reports that NOD mice have increased levels of IL-21 expression compared with diabetes-resistant strains and that this increase in IL-21 is correlated to susceptibility to T1D (34). This study begins to reconcile these conflicting reports by elucidating an important role of IL-21R signaling in the development of spontaneous EAE. It is 
Table 1. Incidence of spontaneous EAE in 2D2xTH, 2D2xTH I/21r KO, and 2D2xTH II23r KO mice

$\begin{array}{lccc}\text { Mice } & \text { Disease incidence (\%) } & \text { Mean score } & \text { Mean week of onset } \\ \text { 2D2xTH } & 28 / 63(44 \%) & 3.1 \pm 0.72 & 8.9 \pm 3.5 \\ \text { 2D2xTH II21r KO } & 11 / 43(25 \%) & 2.3 \pm 1.12 & 14.7 \pm 6.4 \\ \text { 2D2xTH II23r KO } & 0 / 50(0 \%) & \text { NA } & \text { NA }\end{array}$

Incidence of EAE was monitored for 25 weeks after birth. Disease incidence, mean week of onset, and mean score are reported as number of mice affected/total number of mice. NA, not applicable.

possible that active immunization with myelin antigens in CFA induces massive amounts of IL-6 and other inflammatory cytokines (data not shown), which may mask the important role of IL-21 in T cell/B cell interaction.

We next wanted to determine the cytokine profile of the infiltrating $\mathrm{CD}^{+} \mathrm{T}$ cells of the CNS from spontaneous EAE mice. CNS-infiltrating lymphocytes were isolated at the peak of disease from 2D2xTH and 2D2xTH Il21r KO mice and analyzed for IFN- $\gamma$ and IL-17 production. While both IFN- $\gamma$ and IL-17 were decreased in the 2D2xTH Il21r KO mice when compared with 2D2xTH mice, the level of IL-17 was more severely compromised (Figure 1G). Based on the results that IL-17 was compromised in the CNS of 2D2xTH Il21r KO mice, we wanted to confirm the relative expression of ROR $\gamma \mathrm{t}$, the master transcription factor associated with Th17 cells. 2D $2 \mathrm{CD}^{+} \mathrm{T}$ cells from the LNs and SP of 2D 2xTH and 2D2xTH Il21r KO mice that developed disease were sorted, and quantitative RT-PCR was performed for Rorc. Interestingly, the expression of Rorc was comparable between the 2 groups (Figure $1 \mathrm{H})$ even though there was a decrease in IL-17 production in the CNS of 2D2xTH Il21r KO mice, thus suggesting that the decreased incidence in disease may be attributed to other pathogenic factors associated with Th17 cells.

We $(35)$ and others $(36,37)$ have recently reported the existence of both pathogenic and nonpathogenic Th17 cells, and a gene signature of 25 different genes can distinguish the 2 subsets. The decreased disease incidence in 2D2xTH Il21r KO mice prompted us to explore whether there was an IL-21-dependent regulation of pathogenic gene signatures. First, we wanted to determine whether the naive T cells from 2D2xTH cells versus 2D2xTH Il21r KO mice can be equally differentiated into Th1 or Th17 cells. Naive CD $4^{+} \mathrm{T}$ cells were sorted from LNs and SP of 2D2xTH and 2D2xTH Il21r KO mice and were differentiated in vitro into Th1 or Th17 cells. Both Th1 differentiation and Th17 differentiation were compromised in $\mathrm{CD}^{+}{ }^{+} \mathrm{T}$ cells from $2 \mathrm{D} 2 \mathrm{xTH}$ Il21r KO mice, although the difference was greater under Th17 conditions (Figure 1I and Supplemental Figure 1; supplemental material available online with this article; doi:10.1172/ JCI75933DS1). The defect in Th17 differentiation made us wonder whether there were changes in the expression of other genes associated with Th17 pathogenicity and development of EAE. There is a pathogenic signature for Th17 cells (35) that will allow us to determine whether the absence of IL-21R affects genes that influence the pathogenicity of Th17 cells. Indeed, mRNA expression of various genes that have been reported to be part of the pathogenic signature (35), such as Csf2, Cxcl3, Il22, and Il23r, showed reduced expression in $\mathrm{CD}^{+} \mathrm{T}$ cells that were dif- ferentiated in vitro from $2 \mathrm{D} 2 \mathrm{xTH}$ Il21r KO mice (Figure 1J). Interestingly, other sets of genes that have been shown to contribute either positively, such as Ccr6, Gzmb, and Icos, or negatively, such as Ahr and Maf, showed no difference between Th17 cells from 2D2xTH versus 2D2xTH Il21r KO mice (Supplemental Figure 2), suggesting that not all pathogenic and nonpathogenic genes are regulated equally by IL-21. In contrast, production of IL-10, which makes Th17 cells nonpathogenic, was increased in Th17 cells from 2D2xTH Il21r KO mice (Figure 1J). Collectively, the data suggest that $\mathrm{T}$ cells from $2 \mathrm{D} 2 \mathrm{xTH}$ mice lacking IL-21R have a defect in Th17 differentiation as do a number of Th17 genes associated with Th17 pathogenicity, which may have a direct consequence in the incidence of spontaneous EAE. Interestingly, ROR $\gamma \mathrm{t}$ expression was decreased when $\mathrm{T}$ cells from 2D2xTH and 2D2xTH Il21r KO mice were differentiated in vitro (Supplemental Figure 2). This was in contrast to ROR $\gamma$ t expression that was measured when $\mathrm{T}$ cells from sick 2D2xTH mice and 2D2xTH Il21r KO mice were analyzed (Figure 1H). In addition, T cells lacking IL-21R also had compromised IF $\mathrm{N}-\gamma$ production, suggesting Th1 cells also require IL-21 endogenously (24), albeit significantly less than Th17 cells, but that the production of endogenous IL-21 contributes to the expansion/differentiation of Th1 cells (Figure 1I and Supplemental Figure 1). Whether this affects the pathogenic potential of $\mathrm{T}$ cells to induce EAE is unclear, since both Ifng KO and Ifngr KO mice have been shown to develop exacerbated EAE (13-15). Collectively, we show that the absence of IL-21R on both $\mathrm{T}$ and $\mathrm{B}$ cells induces several defects in the development of pathogenic $\mathrm{CD} 4^{+} \mathrm{T}$ cells. Not only are $\mathrm{T}$ cells compromised in activation, survival, and proliferation, but Th17 differentiation and the induction of many of the pathogenic signature genes are also reduced.

T cells from 2D2xTH Il21r KO mice have decreased activation state, proliferative capacity, and cytokine production. To elucidate the mechanisms that reduce the incidence of spontaneous EAE in $2 \mathrm{D} 2 \mathrm{xTH}$ Il21r $\mathrm{KO}$ mice, we wanted to examine the cooperation between MOG-specific T and B cells in the absence of IL$21 \mathrm{R}$ signaling. First, we determined the steady-state activation state of T cells in healthy 2D2xTH and 2D2xTH $\mathrm{Il} 21 \mathrm{r}$ KO mice and found that both groups had comparable naive $2 \mathrm{D} 2 \mathrm{~T}$ cell populations $(\sim 80 \%)$ and $\mathrm{CD} 62 \mathrm{~L}^{+} \mathrm{CD} 44^{+} \mathrm{T}$ cells (Figure $2 \mathrm{~A}$ ), but the 2D2xTH Il21r KO mice had a decreased frequency of CD62 $\mathrm{L}^{-}$ $\mathrm{CD} 44^{+} \mathrm{T}$ cells and $\mathrm{CD} 138^{+} \mathrm{CD} 19^{+}$and $\mathrm{CD} 19^{+} \mathrm{B} 22 \mathrm{O}^{+} \mathrm{B}$ cells from the lymphoid tissues (Figure 2A and Supplemental Figure 3). In order to determine the proliferative capacity of $\mathrm{T}$ cells between 2D2xTH mice and 2D2xTH Il21r KO mice, total LNs and SP cells were stimulated with recombinant MOG protein (rMOG) or $\mathrm{MOG}_{35-55}$ peptide in vitro for 4 days for the assessment of $\mathrm{T}$ cell proliferation. Our data revealed that cells from $2 \mathrm{D} 2 \mathrm{xTH}$ Il21r KO mice have a decreased capacity to proliferate to rMOG but not to $\mathrm{MOG}_{35-55}$ peptide when compared with cells from 2D2xTH mice (Figure 2B). Since both T cells and B cells express IL-21R, we cultured T cells and B cells in the presence of $\mathrm{rMOG}$ 
A

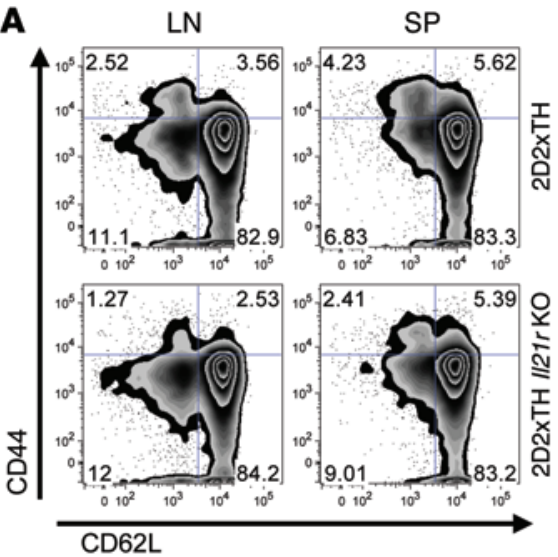

D
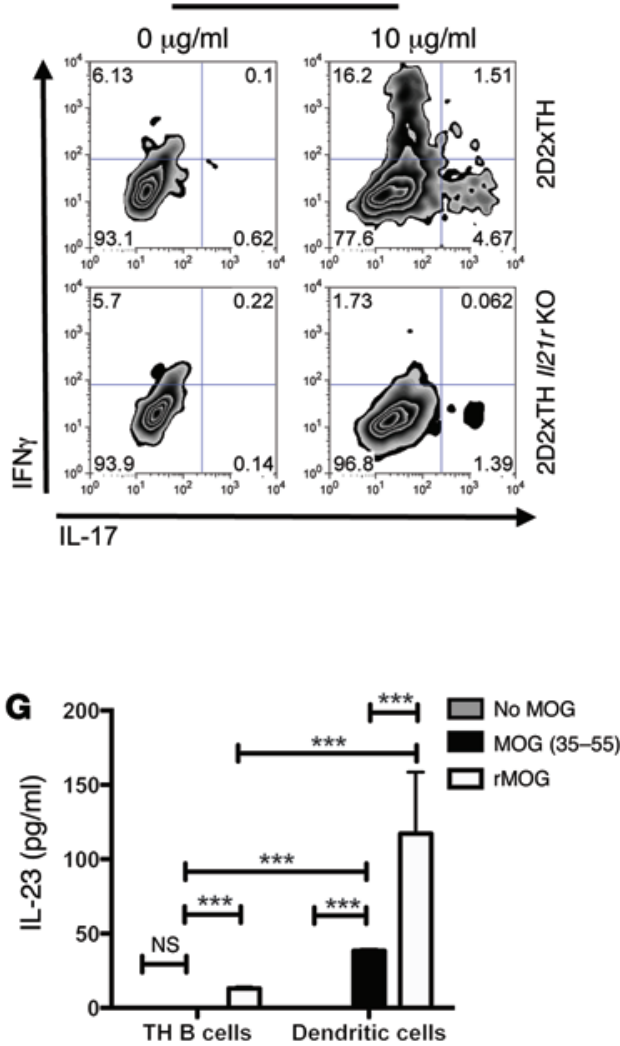

B
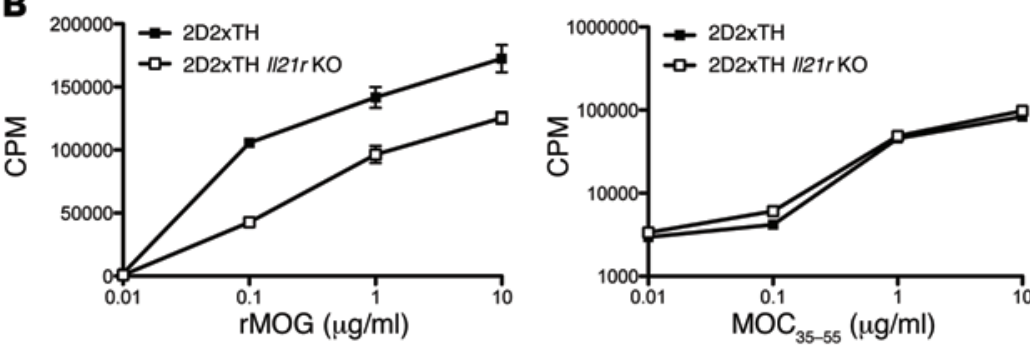

C

2D2 T cells

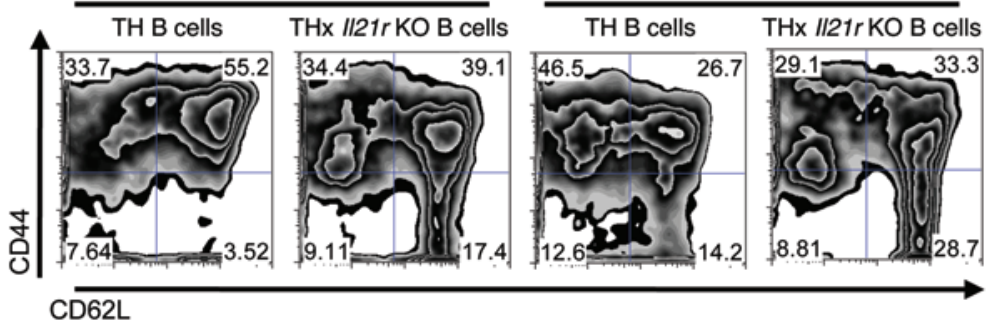

$\mathbf{E}$
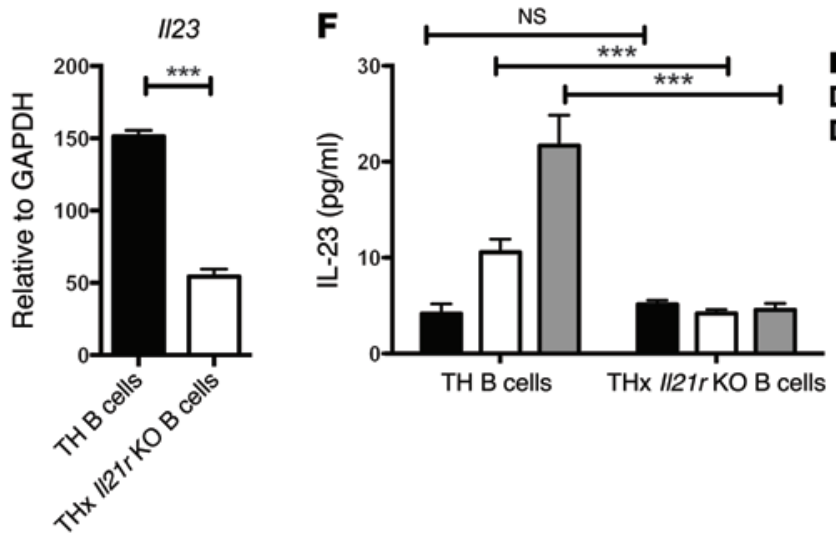

H

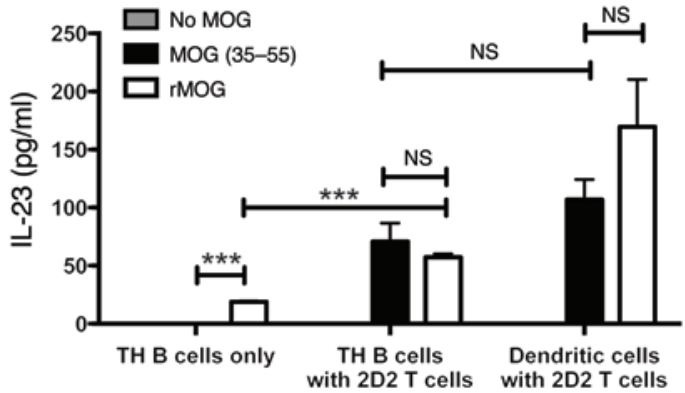

Figure 2. TH B cells lacking IL-21R are poor APCs. (A) Steady-state activation of CD4 ${ }^{+}$T cells from LNs and SP of 2D2xTH and 2D2xTH II21r KO mice that were harvested ex vivo and stained for CD62L and CD44. (B) ${ }^{3} \mathrm{H}$ proliferation assay of T cells stimulated with rMOG (left panel) or MOG ${ }_{35-55}$ (right panel) with varying concentrations of antigen $(0.01 \mu \mathrm{g} / \mathrm{ml}$ to $10 \mu \mathrm{g} / \mathrm{ml})$. (C) Flow cytometry analysis of CD62L and CD44 gated on V $\alpha 3.2^{+} \mathrm{CD} 4^{+} \mathrm{T}$ cells that were cocultured in vitro with rMOG $(10 \mu \mathrm{g} / \mathrm{ml})$ and sorted TH B cells from either 2D2xTH or 2D2xTH II21r KO mice. (D) Intracellular cytokine staining of IFN- $\gamma$ and IL-17 from in vitro-cultured $V \alpha 3.2^{+} \mathrm{CD}^{+}{ }^{+}$T cells that were stimulated with rMOG $(0 \mu \mathrm{g} / \mathrm{ml}$ or $10 \mu \mathrm{g} / \mathrm{ml})$ and IL-23 for 4 days. (E) Quantitative RT-PCR of $/ 123$ mRNA from TH B cells sorted from indicated mice that were cultured in vitro for 4 days with rMOC (10 $\mu \mathrm{g} / \mathrm{ml})$. (F) Cytokine analysis (cytometric bead assay [CBA]) of IL-23 from TH B cells sorted from 2D2xTH and 2D2xTH II21r KO mice that were cultured in vitro for 4 days with rMOG at indicated concentrations. (G) Cytokine analysis (CBA) of IL-23 of TH B cells and DCs sorted from 2D2xTH mice that were cultured in vitro for 4 days with no MOG, MOG $35-55(10 \mu \mathrm{g} / \mathrm{ml})$, or rMOG $(10 \mu \mathrm{g} / \mathrm{ml})$. (H) Cytokine analysis using CBA of IL-23 in TH B cells and DCs (CD11c $)$ sorted from $2 \mathrm{D} 2 \times \mathrm{XTH}$ mice that were cultured in vitro with $2 \mathrm{D2}$ T cells for 4 days with no MOG, $\mathrm{MOG}_{35-55}(10 \mu \mathrm{g} / \mathrm{ml})$, or rMOC $(10 \mu \mathrm{g} / \mathrm{ml})$. Data shown are representative of at least 3 independent experiments with at least $n=3$ mice for each experiment. Data represent mean \pm SEM for $\mathbf{B}$ and $\mathbf{E}-\mathbf{H}$. Statistics were determined by Student's 2-tailed $t$ test. ${ }^{* *} P<0.001$. 
A

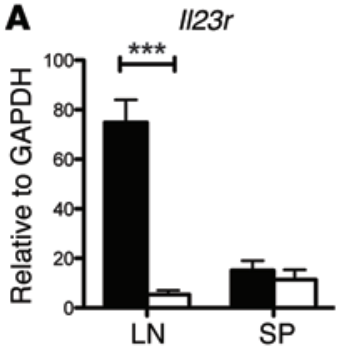

B

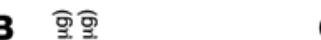

C

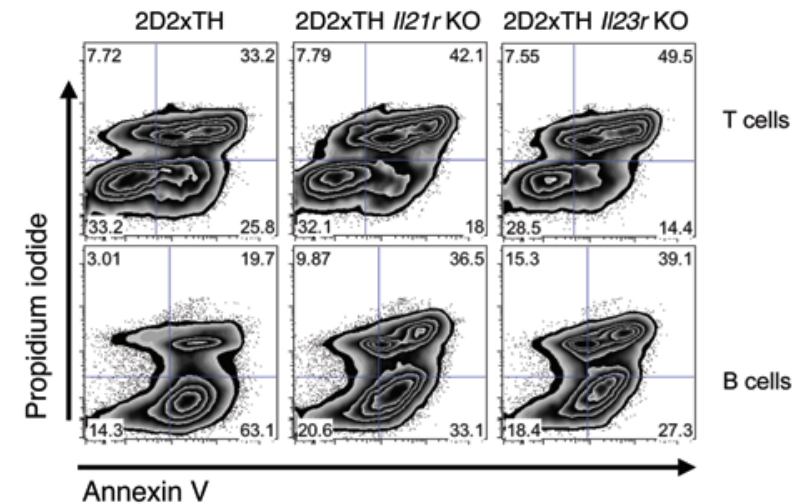

D

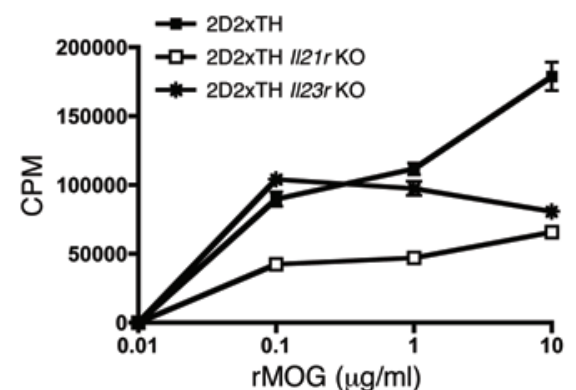

Annexin V
$2 \mathrm{D} 2 \times \mathrm{TH}$

2D2xTH II21r KO

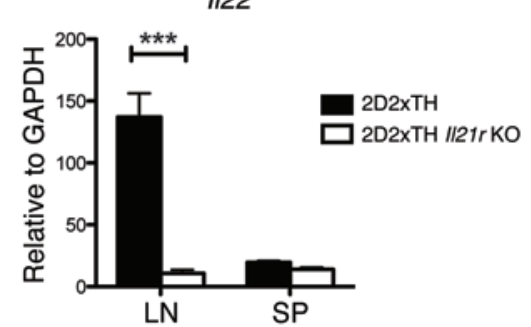

2 Serpine2

13 Stat2

15 Ccr8

161122

17 II9

$\begin{array}{ll}18 & 1 r f 4 \\ 19 & 1127 r a\end{array}$

20 Foxo1

21 II17ra

22 II 4 ra

23 Ccr6

25 Maf

26 Caf

27 Stat6

28 Cd86

29 Cd80

31 Fasl

32 II21r

33 Rora

34 Batf

$\begin{array}{ll}35 & \text { Ahr } \\ 36 & \mathrm{Ccl} 4\end{array}$

37 Pou2af1

38 Cxcr3

$39 \mathrm{Bcl} 3$

40 Hif1a

41 II10ra

42 Tbx21

$\begin{array}{ll}43 & 117 r \\ 44 & 1110\end{array}$

45 Stat 4

46 Rorc

47 Bcl6

48 III $3 r$

49 ll6st

51 Rbp

II21

3 Ccr 4

4 Nfil3

55 Smox

56 Ctla2b

E

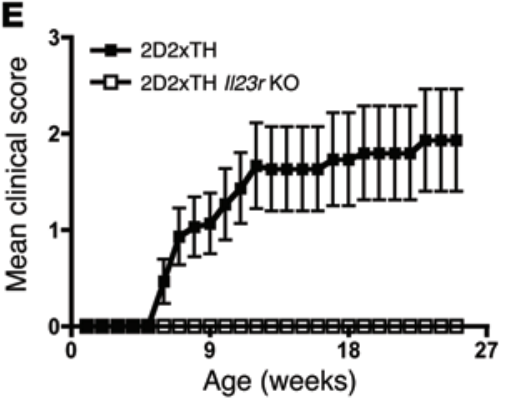

Figure 3. 2D2xTH II23r KO mice are resistant to developing spontaneous EAE. (A) Quantitative RT-PCR of $1 / 22$ and II23r mRNA in $\mathrm{V} \alpha 3.2^{+} \mathrm{CD} 4^{+} \mathrm{T}$ cells in the $\mathrm{LNs}$ and SP of 2D2xTH and 2D2xTH II21r KO mice that developed EAE. (B) nCounter (Nanostring) analysis of $2 \mathrm{D} 2 \mathrm{~T}$ cells sorted from 4-day-cultured LNs and splenocytes from $2 \mathrm{D} 2 \mathrm{XTH}, 2 \mathrm{D} 2 \mathrm{xTH}$ $1 / 21 r \mathrm{KO}$, and 2D2xTH II23r KO mice. Cells were stimulated with either no $\mathrm{rMOG}(0 \mu \mathrm{g} / \mathrm{ml})$ or rMOG $(10 \mu \mathrm{g} / \mathrm{ml})$ in vitro. (C) Flow cytometry analysis of annexin $\mathrm{V}$ and propidium iodide staining from $2 \mathrm{D} 2 \mathrm{~T}$ cells or $\mathrm{TH} B$ cells that were cultured in vitro for 5 days with $\mathrm{PMOC}$ $(10 \mu \mathrm{g} / \mathrm{ml})$ from 2D2xTH, 2D2xTH II21r KO, and $2 \mathrm{D} 2 \times \mathrm{TTH} / \mathrm{I} 23 \mathrm{r} \mathrm{KO}$ mice. (D) ${ }^{3} \mathrm{H}$ proliferation assay of T cells from 2D2xTH, 2D2xTH II21r KO and 2D2xTH II23r KO mice with various concentration of rMOG (0.01-10 $\mu \mathrm{g} / \mathrm{ml})$. (E) Incidence of spontaneous EAE from 2D2xTH $(n=63)$ and 2D2xTH II23r KO $(n=50)$ (F) Quantification of the CNS lesions in the meninges and parenchyma of mice that developed spontaneous EAE. Data shown here are representative of 3 (A and B), 4 (D), or 5 (C) independent experiments with at least $n=3$ mice unless otherwise indicated. Data represent mean \pm SEM for $\mathbf{A}$ and $\mathbf{D}-\mathbf{F}$. ${ }^{* *} P<0.001$. in the absence of IL-21R on T cells or B cells. Four days later, we checked for CD62L and CD44 expression on T cells (Figure 2C). Our data revealed that the absence of IL-21R on T cells or B cells decreased the percentage of CD $44^{+}$effector memory $\mathrm{T}$ cells and increased the percentage of $\mathrm{CD} 62 \mathrm{~L}^{+} \mathrm{CD} 44^{-}$naive $\mathrm{T}$ cells (Figure $2 \mathrm{C}$ ). However, the greatest defect in effector cell generation came when both $\mathrm{T}$ cells and B cells were lacking IL-21R, suggesting that IL-21R may be critical for both inducing $\mathrm{T}$ cell activation and licensing $\mathrm{B}$ cells to become effective antigen-presenting cells (APCs) (Figure 2C). In fact, the absence of IL-21R on both T and $\mathrm{B}$ cells also affected the production of effector cytokines (IFN- $\gamma$
$\mathbf{F}$

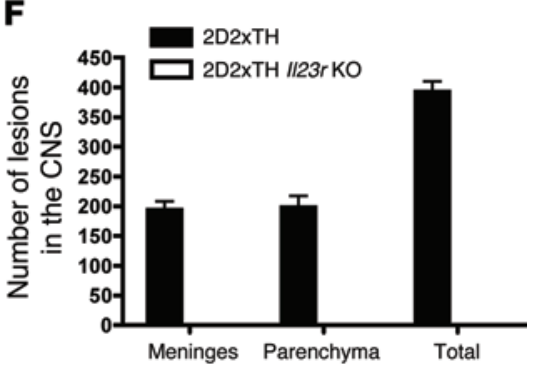

and IL-17) from T cells (Figure 2D). We wondered whether the lack of $\mathrm{T}$ cell stimulation could be attributed in part to the cytokines that $\mathrm{B}$ cells produce to stimulate $\mathrm{T}$ cells. We cultured cells from 2D2xTH or 2D2xTH Il21r KO mice with rMOG in vitro and after 4 days performed quantitative RT-PCR on sorted B cells to determine the expression of Il23, the cytokine that has been shown to be important in the generation/maintenance of Th17 cells and EAE. Our data revealed that B cells from the wild-type 2D2xTH mice, when stimulated with rMOG, produced IL-23, but the IL-23 production was reduced in the B cells from $2 \mathrm{D} 2 \mathrm{xTH}$ Il21r KO mice (Figure 2, E and F). This was shown not only by 
quantitative PCR but also at the protein level by ELISA. Loss of IL-21R signaling reduced IL-23 production to background levels (Figure 2F). Consistently, the addition of IL-21 to B cells could induce expression of IL-23, but the expression of IL-23 by B cells was increased when a TLR-stimulating agent, such as LPS, was added together with IL-21 (Supplemental Figure 4). Even though TH Il21r KO B cells produced less IL-23 when stimulated with rMOG, they did not induce cytokines that are considered to be antiinflammatory, such as IL-10 and IL-35 (Supplemental Figure 5). Since B cells have not been reported to produce IL-23, we wondered how the production compared with professional APCs, such as DCs. We sorted TH B cells and DCs from 2D2xTH mice and cultured them in vitro with either $\mathrm{MOG}_{35-55}$ peptide or rMOG; after 4 days of culture, we measured IL-23 production from supernatants. Compared with DCs, TH B cells produced significantly less IL-23; however, it was interesting to note that there was no IL-23 detected with TH B cells that were stimulated with $\mathrm{MOG}_{35-55}$ peptide, suggesting that $\mathrm{rMOG}$ may be required to fully activate TH B cells in order to produce IL-23 (Figure $2 \mathrm{G}$ ). This trend could also be seen with DCs, where rMOG induced higher production of IL-23 compared with $\mathrm{MOG}_{35-55}$ peptide (Figure $2 \mathrm{G}$ ) However, when we cultured the TH B cells and DCs with 2D2 $\mathrm{T}$ cells, we were able to observe an increase in IL-23 production compared with TH B cell-only cultures (Figure $2 \mathrm{H}$ ), suggesting that the presence of 2D2 T cells may help TH B cells produce more IL-23. Although production of IL-23 from B cells has not been described previously, our data reveal that antigen-specific $B$ cells, when activated in the presence of a relevant antigen, are able to produce IL-23. This was found at the mRNA levels from sorted TH B cells and therefore reduced any doubt that IL-23 was secreted from other APCs. In essence, the B cells from 2D2xTH Il21r KO mice had a defect in IL-23 expression, which likely contributed to the defect in the generation of pathogenic Th17 cells in IL-21R-deficient T cells.

2D2xTH Il23r KO mice are resistant to developing spontaneous EAE. Our data on 2D2xTH Il21r KO mice suggested that the reduced incidence and severity in these mice may be mediated by regulating IL-23 production and responsiveness. Therefore, we analyzed the effects of the loss of IL-21R on the expression of IL-23R on 2D2 T cells. V $23.2^{+} \mathrm{CD} 4^{+} \mathrm{T}$ cells from sick 2D2xTH or 2D2xTH Il21r KO mice were sorted from the LNs and SPs at the peak of disease, and quantitative RT-PCR was performed for the expression of Il23r mRNA. In addition, expression of Il22 mRNA was analyzed, since IL-22 is uniquely dependent on IL-23R signaling $(38,39)$. The expression of both $I l 23 r$ and $I l 22$ was significantly reduced in the $\mathrm{LN}$-derived $\mathrm{T}$ cells from 2D2xTH Il21r KO mice when compared with those from 2D2xTH mice. The expression of both $I l 23 r$ and $I l 22$ in the splenic T cells was rather low and was not markedly different (Figure 3A). This raised the issue of whether the decreased expression of IL-23R could in part be responsible for reduced incidence of disease observed in 2D2xTH Il21r KO mice. To address this issue, we generated 2D2xTH Il23r KO mice. We then compared the gene expression profiles of $2 \mathrm{D} 2 \mathrm{~T}$ cells from 2D2xTH, 2D2xTH Il21r KO, and 2D2xTH Il23r KO mice stimulated in vitro with rMOG $(0 \mu \mathrm{g} / \mathrm{ml}$ or $10 \mu \mathrm{g} / \mathrm{ml})$ by the multiplex qPCR nCounter Analysis system (Nanostring). From a code set comprising 297 effector $\mathrm{T}$ cell genes, we selected 57 genes that have been associated with pathogenicity as well as effector function and generated a comparative heat map between the 3 mouse strains using the no-antigen $(0 \mu \mathrm{g} / \mathrm{ml} \mathrm{rMOG})$ condition specific for each strain as the baseline control. Our heat map revealed that T cells from 2D2xTH Il21r KO and 2D2xTH Il23r KO mice have a comparable gene expression profile with a stronger covariance when compared with $\mathrm{T}$ cells from 2D2xTH T mice (Figure 3B). Some of the key molecules, such as Il23r, Ccr6, Il22, Cd86, and Gmcsf, that are responsible for effector functions and regulate autoimmunity were decreased in T cells from 2D2xTH Il21r KO and 2D2xTH Il23r KO mice, but were increased in T cells from 2D2xTH mice (Figure 3B). This suggests that the decrease in IL23R expression in 2D2xTH Il21r KO mice may be partly responsible for the decreased disease incidence and severity observed in the 2D2xTH Il21r KO mice. In addition to its importance in EAE, IL-23R expression on $\mathrm{T}$ cells has also been shown to affect expansion, survival, and effector T cell function $(40,41)$. We wondered whether the downregulation of IL-23R in T cells from 2D2xTH Il21r $\mathrm{KO}$ mice affected $\mathrm{T}$ cell survival and proliferation. We first wanted to determine the effect of cell survival. LNs and SP cells from 2D2xTH, 2D2xTH Il21r KO, and 2D2xTH Il23r KO mice were cultured in vitro with rMOG and, 4 days later, the frequency of annexin $\mathrm{V}$ - and propidium iodide-positive cells was determined by flow cytometry. Our data revealed that $2 \mathrm{D} 2 \mathrm{~T}$ and $\mathrm{TH}$ B cells from both 2D2xTH Il21r KO and 2D2xTH Il23r KO mice had an increased number of late apoptotic and/or necrotic cells compared with 2D2xTH cells (Figure 3C) and the T cells from these mice did not proliferate as well as T cells from 2D2xTH cells (Figure 3D). However, the defect in proliferation was more profound in T cells from $\mathrm{Il} 21 r \mathrm{KO}$ mice than from $\mathrm{Il} 23 \mathrm{r} \mathrm{KO}$ mice (Figure 3D), suggesting that IL-21 may be more critical than IL-23 for eliciting proliferation for T cells and also implying that the lack of IL-21R on B cells may affect their function as effective APCs.

In active EAE induction, mice lacking IL-23R or IL-23 are completely protected from developing the disease $(16,42)$. However, in our spontaneous EAE model in which $\mathrm{T}$ cell/B cell cooperation was required for antigen-specific $\mathrm{T}$ cell activation, proliferation, and pathogenicity, the defect in IL-21/IL-21R signaling seems to have had a more profound adverse effect on the function of both $\mathrm{T}$ and B cells, especially when compared with mice lacking IL-23:IL23R signaling. Thus, we wondered whether mice lacking IL-21R would confer greater protection in our spontaneous EAE model compared with mice lacking IL-23R. To determine this, we monitored the spontaneous disease development of 2D2xTH Il23r KO mice. To our surprise, mice lacking IL-23R were completely protected from developing spontaneous EAE (Figure 3E), suggesting that even in our spontaneous model, IL-23R is critical for driving pathogenicity. Histopathological analysis of the lesions in the CNS from 2D2xTH and 2D2xTH Il23r KO mice revealed that there are no histopathological lesions in the CNS (Figure 3F), suggesting that the absence of IL-23R prevented spontaneous EAE development even better than the absence of IL-21R in 2D2xTH Il21r KO mice. In addition, loss of IL-23R signaling completely abolished development of ectopic lymphoid follicles in 2D2xTH mice (Supplemental Figure 6). This may be due in part to the fact that the loss of IL-21R only partially inhibits IL-23R expression on $\mathrm{T}$ cells and IL-23 production from B cells. 


\section{Discussion}

There has been a growing body of evidence implicating Th17 cells in the pathogenesis of autoimmunity in both mice and humans. Inhibiting key effector cytokines critical for Th17 development has shown a concomitant reduction in tissue inflammation and disease progression (43). Furthermore, central to Th17 polarization is the role of IL-21, which can function as an initial differentiating factor or as a critical amplification component during Th17 development $(24,44)$. However, conflicting reports implicate the role of IL-21 in EAE as either essential (28) or dispensable $(29,30)$. This study begins to reconcile conflicting reports of IL-21R signaling in the development of EAE. Our data reveal that IL-21/IL-21R signaling is indeed critical for encephalitogenic $\mathrm{T}$ cell activation and function as well as Th17 development, which ultimately affect the development of spontaneous disease.

In fact, secreted IL-21, which feeds back into activated Th17 cells in an autocrine manner, has been shown to be critical for maintaining IL-21R expression on T cells $(24,44)$. Similarly, in IL-21R-deficient NOD mice, which are resistant to the development of spontaneous T1D, there is a defect in Th17 polarization that is both $\mathrm{T}$ cell intrinsic and $\mathrm{CD}_{11} \mathrm{~b}^{+}$cell mediated (45). It is possible that IL-21/IL-21R signaling modulates APC function, including that of B cells when they act as APCs (46), by inducing proinflammatory mediators that feed back into $\mathrm{T}$ cells to propagate Th17 cell differentiation (45). Indeed, given that IL- 6 from APCs induces IL-21 from T cells (47) and that IL-21 is critical for B cell maturation, survival, and function $(48,49)$, the mutual cooperation between $\mathrm{T}$ and $\mathrm{B}$ cells in an autoimmune-susceptible model is highly conducive to the generation of pathogenic Th17 cells.

Interestingly, our data reveal that, while IL-17 production was consistently compromised in T cells lacking IL-21R both in vitro and in vivo, the expression of ROR $\gamma \mathrm{t}$ was affected only in in vitrodifferentiated Th17 cells and not in $\mathrm{CD}^{+}{ }^{+} \mathrm{T}$ cells harvested from diseased 2D2xTH Il21r KO mice. One possible interpretation for the discrepancy could be that it is due to the method of activation as well as the kinetics of Th17 differentiation. On the one hand, $2 \mathrm{D} 2 \mathrm{~T}$ cells activated in vivo require APCs presenting MOG in conjunction with a cohort of secrete cytokines, not limited to TGF- $\beta$ and IL-6, during a span of several weeks to induce spontaneous disease. On the other hand, $\mathrm{T}$ cells activated in vitro require platebound anti-CD3 and anti-CD28 along with TGF- $\beta$ and IL- 6 in a 4-day time span. Compared with Th1 or Th2 subsets, Th17 cells are unique in that the differentiating cytokine is different from the proliferation cytokine, such that IL-21 is an autocrine factor that is required mainly for the proliferative phase of Th17 cells and ROR $\gamma \mathrm{t}$ expression is induced with the differentiating cytokine cocktail of TGF- $\beta$ and IL-6 (44). For in vivo experiments, it is possible that other factors are in play to maintain ROR $\gamma \mathrm{t}$ expression, while the lack of IL-21R prevents proliferation of Th17 cells, which results in the observed decrease in IL-17.

Our data also reveal that activated B cells can produce IL-23, a cytokine that has been associated with increasing the pathogenic potential of $\mathrm{CD}^{+} \mathrm{T}$ cells, specifically in the stabilization, maintenance, and survival of Th17 cells, and that has been shown to be the best inducer of IL-23R on T cells (44). It should be noted that, even though DCs produce more IL-23 than TH B cells (Figure 2, G and H), 2D2 transgenic mice that have a MOG-specific TcR but a normal DC population do not develop spontaneous EAE (9). This is highly suggestive of the possibility that the TH B cells, when acting as APCs to 2D2 T cells in 2D2xTH mice, may be the better APCs to induce spontaneous EAE. In addition, it has been shown that mice depleted of the myeloid APC subset can still develop EAE when induced by rMOG protein (50). Our data suggest that the absence of IL-21R on B cells can affect IL-23 production by B cells, which in turn may affect $\mathrm{T}$ cell pathogenicity and function. Although production of IL-23 from B cells has not been described previously, our data reveal that antigen-specific B cells, when activated in the presence of a relevant antigen, are able to produce IL-23. This production of IL-23 was dependent in part on the TH B cells expressing IL-21R, which likely contributed to the generation of pathogenic Th17 cells.

Conversely, the role of IL-21 on $\mathrm{CD}^{+} \mathrm{T}$ cells has been shown to be important for the induction of IL-23R, and we and others (35-37) have observed that IL-23R expression on effector T cells is critical for evoking the pathogenic potential of Th17 cells. Thus, it is also possible that IL-21 signaling acts directly on T cells to induce Th17 cell development and IL-23R expression, which in turn further maintain and stabilize the Th17 phenotype. Therefore, in the 2D2xTH disease model of spontaneous autoimmunity, where $\mathrm{T}$ cell/B cell collaboration is essential for disease induction, the lack of IL-21R on T cells may adversely affect B cell function, which may then prevent efficient antigen presentation and production of inflammatory cytokines, such as IL-6 and IL-23. Indeed, TH B cells, when stimulated by rMOG, are able to secrete IL- 6 and IL-23 and promote IL-17 production from T cells (data not shown). It remains to be determined whether the loss of IL-23 production by $\mathrm{B}$ cells in 2D2xTH Il21r KO mice directly limits IL-23R expression on $\mathrm{T}$ cells or whether the decrease in IL-23R expression is through the direct loss of IL-21/IL-21R signaling.

Future experiments need to explore the potential pathogenic factor or factors that are induced upon IL-23 signaling for the development of EAE in both spontaneous and induced models. In summary, IL-21, which has not been shown to be essential for the induction of active EAE, plays an important role in the development of spontaneous NMO-like disease in the 2D2xTH model. Understanding the mechanism by which Th17 cells and antigenspecific B cells promote pathogenicity may be useful for the development of future novel therapies for MS. Successful clinical trials with the B cell-depleting therapy rituximab (51) are just one example showing that B cells might be a playing a critical role in the development of $\mathrm{T}$ cell-mediated autoimmune disease.

\section{Methods}

Mice. $\mathrm{MOG}_{35-55}$-specific TCR transgenic mice on a C57BL/6 background (referred to as 2D2 mice) and MOG-specific B cell receptor "knockin" mice (referred to as TH mice) generated by replacing the germline JH locus with the rearranged Ig-heavy-chain (IgH) variable (V) gene from MOG-specific monoclonal antibodies were described previously (10). The 2D2xTH Il21r KO and 2D2xTH Il23r KO mice were generated by crossing 2D2xTH mice with the Il21r KO and IL23R KO mice, respectively. All mice were housed and maintained in a conventional pathogen-free facility at the Harvard Institute of Medicine (Boston, Massachusetts, USA). 
Antigens. $\mathrm{MOG}_{35-55}$ peptide (MEVGWYRSPFSRVVHLYRNGK) was obtained from the Biopolymer Facility, Center for Neurological Diseases, Brigham and Women's Hospital. A plasmid construct encoding the extracellular domain of rat MOG protein $\left(\mathrm{MOG}_{1-125}\right)$ was provided by C. Linington (University of Aberdeen, Aberdeen, United Kingdom); rMOG protein was purified from inclusion bodies (52).

Cell isolation, sorting, and intracellular cytokine staining. $\mathrm{T}$ and B cells were isolated from SPs and LNs and purified using CD4 and B220 microbeads for positive selection according to the manufacturer's instructions (Miltenyi Biotec). Naive T cells were sorted with anti-CD4-PerCP (clone RM4-5), anti-CD62L-APC (clone MEL-14), and anti-CD44-PE (clone IM7) antibodies (all BioLegend). 2D2 T cells were sorted with anti-V $\alpha 3.2-$ FITC (clone RR3-16) and anti-CD4-APC (clone RM4-5) (all BioLegend). TH B cells were sorted with rMOG-PE (52) and anti-CD19-APC (clone 6D5) (BioLegend). For intracellular cytokine staining (ICC), cells were stimulated with PMA (50 ng ml-1, Sigma-Aldrich) and ionomycin (1 $\mu \mathrm{g}$ $\mathrm{ml}^{-1}$, Sigma-Aldrich) and a protein transport inhibitor containing monen$\sin$ (GoligiStop) (BD Biosciences) for 4 hours prior to detection with antibodies. Surface markers were stained in PBS with $1 \%$ FCS for 20 minutes at room temperature, then subsequently fixed in Cytoperm/Cytofix (BD Biosciences), permeabilized with Perm/Wash Buffer (BD Biosciences), and stained with cytokine antibodies (anti-IFN- $\gamma$-APC, anti-IL-17AAlexa Fluor 488, all from BioLegend) diluted in Perm/Wash buffer as described previously (53). All flow cytometry data were acquired on a BD LSRII and analyzed with FlowJo software (TreeStar).

Proliferation assays. Cells were grown in DMEM supplemented with $10 \%$ FCS, $\beta$-mercaptoethanol, L-glutamine, gentamicin sulfate, and penicillin/streptomycin. For thymidine proliferation assay, either 3 $\times 10^{6}$ cells $/ \mathrm{ml}$ total splenocytes or $3 \times 10^{5}$ cells $/ \mathrm{ml}$ purified $\mathrm{V} \alpha 3.2^{+} \mathrm{CD} 4^{+}$ cells with $1.5 \times 10^{6}$ cells $/ \mathrm{ml}$ purified $\mathrm{CD} 19^{+} \mathrm{B}$ cells were cultured for 72 hours in round-bottom 96 -well plates in the presence of various concentrations of the rMOG protein or $\mathrm{MOG}_{35-55}$ peptide (range, 0.01-10 $\mu \mathrm{g} / \mathrm{ml}$ ). Cells were pulsed with $1 \mu \mathrm{Ci}^{3} \mathrm{H}$ thymidine for the last 16 hours of incubation. Mean thymidine incorporation in triplicate wells was measured using a $\beta$ counter (LS 5000; Beckman Coulter).

Real-time PCR. 2D2 CD4 ${ }^{+}$T cells and TH B cells were sorted after 4 days of culture with rMOG; RNA was extracted with the RNeasy Kit (QIAGEN), reverse transcribed using the iScript cDNA Synthesis Kit (Bio-Rad), and analyzed by quantitative RT-PCR with vii7 Real-Time PCR Systems (Applied Biosystems) for the gene of interest. Primer/ probe mixtures were purchased from Applied Biosystems. The comparative threshold cycle method and an internal control (Gapdh) were use for normalization of the target genes. Primers and probes from Applied Biosystems were as follows: Cxcl3: Mm01701838 m1; Csf2: Mm01290062_m1; Gzmb: Mm00442834_m1; Il17a: Mm00439618_m1; Maf: Mm02581355_s1; Il22: Mm00444241_m1; Il23r: Mm00519943_m1; Rorc: Mm00441144_g1; GAPDH: 4352339E; Il10: Mm00439614_m1; Ccr6: Mm99999114_s1; Il21: Mm00517640_ $\mathrm{m1}$; Ahr: Mm00478932_m1; and Icos: Mm00497600_m1

Spontaneous EAE. Clinical assessment of EAE was performed weekly after 4 weeks of age, and mice were scored for disease according to the following criteria: 0 , no disease; 1 , decreased tail tone; 2 , hind-limb weakness or partial paralysis; 3 , complete hind-limb paralysis; 4, front- and hind-limb paralysis; and 5 , moribund state.

In vitro $T$ cell differentiation. $\mathrm{CD} 4^{+} \mathrm{T}$ cells were purified from $\mathrm{SP}$ and LNs using anti-CD4 microbeads (Miltenyi Biotech), then further sorted for naive $\mathrm{CD} 4{ }^{+} \mathrm{CD} 62 \mathrm{~L}^{\text {hi }} \mathrm{CD} 44^{\text {lo }} \mathrm{T}$ cells. Sorted cells were acti- vated with plate-bound anti-CD3 $(2 \mu \mathrm{g} / \mathrm{ml})$ and anti-CD28 $(2 \mu \mathrm{g} / \mathrm{ml})$ (both Bioxcell). Th17 differentiation used $2 \mathrm{ng} / \mathrm{ml}$ of rhTGF- $\beta 3$ (Miltenyi Biotec) and $25 \mathrm{ng} / \mathrm{ml}$ of rmIL-6 (Miltenyi Biotec). Th1 differentiation used $20 \mathrm{ng} / \mathrm{ml}$ of IL-12 (Miltenyi Biotec). Cells were cultured for 4 days and harvested for RNA, ICC, and flow cytometry.

Histology. Animals were sacrificed after 4 months of observation for development of clinical signs of EAE. Brains, spinal cords, and optic nerves were removed and fixed in 10\% formalin. Paraffinembedded sections were stained with luxol fast blue H\&E. Inflammatory foci ( $>10$ mononuclear cells) in the meninges and parenchyma and leptomeningeal lymphoid follicles were counted by a pathologist in a blinded manner, so that disease status of the mice as well as the genotype were not revealed.

Analysis of CNS-infiltrating mononuclear cells. At the peak of disease, mice were sacrificed for analysis of CNS-infiltrating cells. Mice were perfused through the left ventricle of the heart with cold PBS. The brain and the spinal cord were flushed out with PBS by hydrostatic pressure. CNS tissue was minced with a sharp razor blade and digested with collagenase D $(2.5 \mathrm{mg} / \mathrm{ml}$, Roche Diagnostics) and DNaseI $\left(1 \mathrm{mg} / \mathrm{ml}\right.$, Sigma-Aldrich) at $37^{\circ} \mathrm{C}$ for 20 minutes. Mononuclear cells were isolated by passing the tissue through a cell strainer $(70 \mu \mathrm{m})$, followed by Percoll gradient (37\% and 70\%) centrifugation. Mononuclear cells in the interphase were removed, washed, and resuspended in culture medium for analysis by ICC.

NanoString gene expression analysis. 2D2 CD4 ${ }^{+} \mathrm{T}$ cells were sorted after 4 days of in vitro rMOG $(0 \mu \mathrm{g} / \mathrm{ml}$ or $10 \mu \mathrm{g} / \mathrm{ml})$ stimulation of LNs and splenocytes from 2D2xTH, 2D2xTH Il21r KO, and 2D2xTH Il23r KO mice. Cells were immediately lysed using RLT buffer (QIAGEN), and RNA was purified according to the manufacturer's protocol. Cell lysates were hybridized with a custom-made CodeSet provided by NanoString Technologies Inc. Bar codes were counted (1,150 fields of view per sample) on an nCounter Digital Analyzer. Data were processed using nSolver Analysis Software by normalization to the geometric mean of the positive control spike count in addition to the 4 reference genes (Actv, Gapdh, Hprt, and Tubb5). A heat map was generated from the relative fold change by $10 \mu \mathrm{g} / \mathrm{ml} \mathrm{rMOG}$ gene expression compared with $0 \mu \mathrm{g} / \mathrm{ml} \mathrm{rMOG}$ gene expression, which were used as gene expression baseline controls.

Statistics. GraphPad Prism 4.0 was used for statistical analysis (linear regression with 95\% confidence interval and unpaired, 2-tailed Student's $t$ test). Differences were considered statistically significant at $P<0.05$. Linear regression analysis of EAE data was performed using GraphPad Prism software.

Study approval. Studies in animals were reviewed and approved by the Harvard Medical Area Standing Committee on Animals at the Harvard Medical School.

\section{Acknowledgments}

We thank D. Kozoriz for cell sorting. This work was supported by National MS Society grant RG5030, NIH grant P01 AI045757, NIH grant R01 NS030843, and the Guthy Jackson Charitable Foundation. M. Mitsdoerffer (Mi 1221/1-1 and SyNergy) was supported by the Deutsche Forschungsgemeinschaft.

Address correspondence to: Vijay K. Kuchroo, 77 Avenue Louis Pasteur, HIM 785, Boston, Massachusetts 02115, USA. Phone: 617.525.5350; E-mail: vkuchroo@evergrande.hms.harvard.edu. 
1. Lassmann H. Neuropathology in multiple sclerosis: new concepts. Mult Scler. 1998;4(3):93-98.

2. Poser CM, Brinar VV. The nature of multiple sclerosis. Clin Neurol Neurosurg. 2004;106(3):159-171.

3. Furlan R, Cuomo C, Martino G. Animal models of multiple sclerosis. Methods Mol Biol. 2009;549:157-173.

4. Bigazzi PE. Animal models of multiple sclerosis. Clin Immunol Immunopathol. 1995;77(1):3.

5. Greer JM, Sobel RA, Sette A, Southwood S, Lees MB, Kuchroo VK. Immunogenic and encephalitogenic epitope clusters of myelin proteolipid protein. JImmunol. 1996;156(1):371-379.

6. Greer JM, Kuchroo VK, Sobel RA, Lees MB. Identification and characterization of a second encephalitogenic determinant of myelin proteolipid protein (residues 178-191) for SJL mice. JImmunol. 1992;149(3):783-788.

7. Goverman J, Woods A, Larson L, Weiner LP, Hood L, Zaller DM. Transgenic mice that express a myelin basic protein-specific $\mathrm{T}$ cell receptor develop spontaneous autoimmunity. Cell. 1993;72(4):551-560.

8. Waldner H, Whitters MJ, Sobel RA, Collins M, Kuchroo VK. Fulminant spontaneous autoimmunity of the central nervous system in mice transgenic for the myelin proteolipid proteinspecific T cell receptor. Proc Natl Acad Sci U S A. 2000;97(7):3412-3417.

9. Bettelli E, Pagany M, Weiner HL, Linington C, Sobel RA, Kuchroo VK. Myelin oligodendrocyte glycoprotein-specific $\mathrm{T}$ cell receptor transgenic mice develop spontaneous autoimmune optic neuritis. J Exp Med. 2003;197(9):1073-1081.

10. Bettelli E, Baeten D, Jager A, Sobel RA, Kuchroo VK. Myelin oligodendrocyte glycoprotein-specific $\mathrm{T}$ and $\mathrm{B}$ cells cooperate to induce a Devic-like disease in mice. JClin Invest. 2006;116(9):2393-2402.

11. Mandler RN. Neuromyelitis opticaDevic's syndrome, update. Autoimmun Rev. 2006;5(8):537-543.

12. Kuchroo VK, Anderson AC, Waldner H, Munder M, Bettelli E, Nicholson LB. T cell response in experimental autoimmune encephalomyelitis (EAE): role of self and cross-reactive antigens in shaping, tuning, and regulating the autopathogenic T cell repertoire. Annu Rev Immunol. 2002;20:101-123.

13. Ferber IA, et al. Mice with a disrupted IFN- $\gamma$ gene are susceptible to the induction of experimental autoimmune encephalomyelitis (EAE). J Immunol. 1996;156(1):5-7.

14. Wildbaum G, Youssef S, Grabie N, Karin N. Neutralizing antibodies to IFN- $\gamma$-inducing factor prevent experimental autoimmune encephalomyelitis. JImmunol. 1998;161(11):6368-6374.

15. Willenborg DO, Fordham S, Bernard CC, Cowden WB, Ramshaw IA. IFN- $\gamma$ plays a critical down-regulatory role in the induction and effector phase of myelin oligodendrocyte glycoprotein-induced autoimmune encephalomyelitis. J Immunol. 1996;157(8):3223-3227.

16. Cua DJ, et al. Interleukin-23 rather than interleukin-12 is the critical cytokine for autoimmune inflammation of the brain. Nature. 2003;421(6924):744-748.
17. Littman DR, Rudensky AY. Th17 and regulatory T cells in mediating and restraining inflammation. Cell. 2010;140(6):845-858.

18. Ivanov II, et al. The orphan nuclear receptor ROR $\gamma \mathrm{t}$ directs the differentiation program of proinflammatory IL-17 ${ }^{+} \mathrm{T}$ helper cells. Cell. 2006;126(6):1121-1133.

19. Komiyama Y, et al. IL-17 plays an important role in the development of experimental autoimmune encephalomyelitis. JImmunol. 2006;177(1):566-573.

20. $\mathrm{Hu}$ Y, et al. IL-17RC is required for IL-17A- and IL-17F-dependent signaling and the pathogenesis of experimental autoimmune encephalomyelitis. J Immunol. 2010;184(8):4307-4316.

21. Codarri L, et al. ROR $\gamma \mathrm{t}$ drives production of the cytokine GM-CSF in helper T cells, which is essential for the effector phase of autoimmune neuroinflammation. Nat Immunol. 2011;12(6):560-567.

22. Mangan PR, et al. Transforming growth factor- $\beta$ induces development of the $\mathrm{T}(\mathrm{H}) 17$ lineage. Nature. 2006;441(7090):231-234

23. Veldhoen $M$, et al. Transforming growth factor- $\beta$ 'reprograms' the differentiation of T helper 2 cells and promotes an interleukin 9-producing subset. Nat Immunol. 2008;9(12):1341-1346.

24. Korn T, et al. IL-21 initiates an alternative pathway to induce proinflammatory $\mathrm{T}(\mathrm{H}) 17$ cells. Nature. 2007;448(7152):484-487.

25. Bettelli E, et al. Reciprocal developmental pathways for the generation of pathogenic effector TH17 and regulatory T cells. Nature. 2006;441(7090):235-238.

26. Korn T, et al. IL-6 controls Th17 immunity in vivo by inhibiting the conversion of conventional T cells into Foxp $3^{+}$regulatory T cells. Proc Natl Acad Sci U S A. 2008;105(47):18460-18465.

27. Veldhoen M, Hocking RJ, Flavell RA, Stockinger B. Signals mediated by transforming growth factor-beta initiate autoimmune encephalomyelitis, but chronic inflammation is needed to sustain disease. Nat Immunol. 2006;7(11):1151-1156.

28. Nurieva R, et al. Essential autocrine regulation by IL-21 in the generation of inflammatory T cells. Nature. 2007;448(7152):480-483.

29. Coquet JM, Chakravarti S, Smyth MJ, Godfrey DI. Cutting edge: IL-21 is not essential for Th17 differentiation or experimental autoimmune encephalomyelitis. JImmunol. 2008;180(11):7097-7101.

30. Sonderegger I, Kisielow J, Meier R, King C, Kopf M. IL-21 and IL-21R are not required for development of Th17 cells and autoimmunity in vivo. Eur Jimmunol. 2008;38(7):1833-1838.

31. Sutherland AP, et al. Interleukin-21 is required for the development of type 1 diabetes in NOD mice. Diabetes. 2009;58(5):1144-1155.

32. Spolski R, Kashyap M, Robinson C, Yu Z, Leonard WJ. IL-21 signaling is critical for the development of type I diabetes in the NOD mouse. Proc Natl Acad Sci U S A. 2008;105(37):14028-14033.

33. Datta S, Sarvetnick NE. IL-21 limits peripheral lymphocyte numbers through $\mathrm{T}$ cell homeostatic mechanisms. PLoS One. 2008;3(9):e3118.

34. King C, Ilic A, Koelsch K, Sarvetnick N. Homeostatic expansion of T cells during immune insufficiency generates autoimmunity. Cell. 2004;117(2):265-277.

35. Lee $Y$, et al. Induction and molecular signature of pathogenic TH17 cells. Nat Immunol. 2012;13(10):991-999.

36. Ghoreschi K, et al. Generation of pathogenic $\mathrm{T}(\mathrm{H}) 17$ cells in the absence of TGF- $\beta$ signalling. Nature. 2010;467(7318):967-971.

37. Zielinski CE, et al. Pathogen-induced human TH17 cells produce IFN- $\gamma$ or IL-10 and are regulated by IL-1 $\beta$. Nature. 2012;484(7395):514-518.

38. Zheng Y, et al. Interleukin-22, a T(H)17 cytokine, mediates IL-23-induced dermal inflammation and acanthosis. Nature. 2007;445(7128):648-651.

39. Mabuchi T, et al. CCR6 is required for epidermal trafficking of gammadelta-T cells in an IL-23-induced model of psoriasiform dermatitis. JInvest Dermatol. 2013;133(1):164-171.

40. Ahern PP, et al. Interleukin-23 drives intestinal inflammation through direct activity on T cells. Immunity. 2010;33(2):279-288.

41. McGeachy MJ, et al. The interleukin 23 receptor is essential for the terminal differentiation of interleukin 17-producing effector T helper cells in vivo. Nat Immunol. 2009;10(3):314-324.

42. Langrish CL, et al. IL-23 drives a pathogenic T cell population that induces autoimmune inflammation. J Exp Med. 2005;201(2):233-240.

43. Dong C. Targeting Th17 cells in immune diseases. Cell Res. 2014;24(8):901-903.

44. Korn T, Bettelli E, Oukka M, Kuchroo VK. IL-17 and Th17 cells. Annu Rev Immunol. 2009;27:485-517.

45. Liu SM, et al. Differential IL-21 signaling in APCs leads to disparate Th17 differentiation in diabetes-susceptible NOD and diabetes-resistant NOD. J Clin Invest. 2011;121(11):4303-4310.

46. Molnarfi N, et al. MHC class II-dependent B cell APC function is required for induction of CNS autoimmunity independent of myelin-specific antibodies. JExp Med. 2013;210(13):2921-2937.

47. Zhou L. IL-6 programs T(H)-17 cell differentiation by promoting sequential engagement of the IL-21 and IL-23 pathways. Nat Immunol. 2007;8(9):967-974.

48. Linterman MA, et al. IL-21 acts directly on B cells to regulate Bcl- 6 expression and germinal center responses. J Exp Med. 2010;207(2):353-363.

49. Zotos D, et al. IL-21 regulates germinal center B cell differentiation and proliferation through a B cell-intrinsic mechanism. J Exp Med. 2010;207(2):365-378.

50. Isaksson M, Lundgren BA, Ahlgren KM, Kampe O, Lobell A. Conditional DC depletion does not affect priming of encephalitogenic Th cells in EAE. Eur J Immunol. 2012;42(10):2555-2563.

51. Browning JL. B cells move to centre stage: novel opportunities for autoimmune disease treatment. Nat Rev Drug Discov. 2006;5(7):564-576.

52. Adelmann $\mathrm{M}$, et al. The $\mathrm{N}$-terminal domain of the myelin oligodendrocyte glycoprotein (MOG) induces acute demyelinating experimental autoimmune encephalomyelitis in the Lewis rat. J Neuroimmunol. 1995;63(1):17-27.

53. Mitsdoerffer M, et al. Proinflammatory T helper type 17 cells are effective B-cell helpers. Proc Natl Acad Sci U S A. 2010;107(32):14292-14297. 